\title{
Integrated power, water and salt generation: a discussion paper
}

\author{
M Ahmed ${ }^{1}$, A Arakel $^{2}$, D Hoey ${ }^{3}$, M Coleman $^{4}$,
}

${ }^{1}$ Dr Mushtaque Ahmed, Assistant Professor, Department of Soils and Water Sciences, Sultan Qaboos University, PO Box 34 Postal Code 123 Al-Khod, Sultanate of Oman, Phone 968515 212, Fax 968515 418, email ahmedm@squ.edu.om

${ }^{2}$ Dr Aro Arakel, Director, Geo-Processors Pty Ltd, PO Box 290, Pennant Hills, NSW, 2114, Australia, Phone 61299801622 Fax 6129980 8067, email gppl4005@s054.aone.net.au

${ }^{3}$ David Hoey, Senior Environmental Officer, Department of Land and Water Conservation, PO Box 2185, Dangar, NSW, 2309, Australia, Phone 6124960 5019, Fax 6124960 5042, email dhoey@dlwc.nsw.gov.au

${ }^{4}$ Mark Coleman, Partner, Actis Environmental Services, 33 Anstey St, Mundijong, Western Australia 6123, Phone 6189525 5806, Fax 6189525 5807, email actis@iinet.net.au

\begin{abstract}
Cogeneration of electricity and desalinised water - for water production - is an accepted principle in many countries. However, there is an opportunity to extend the concept to obtain greater efficiencies by reassessing the desalination paradigm. The new paradigm considers desalination as only part of the saline water processing chain. It looks at value-adding opportunities through further processing of salt byproducts, particularly bitterns. It considers aspects such as multiple use of evaporation basins, electricity generation from solar ponds using bitterns as a main constituent, and opportunities for resource recovery from bitterns. Above all, it considers the integration of water, salt and power production, as a mutually supporting system.
\end{abstract}

The overall concept of better integration of water, salt and power production is discussed with a focus on the utilisation of saline effluent from desalination plants.

\section{Introduction}

Demands for freshwater are continually increasing. Land salinisation is increasing across the world, and as a result, large volumes of saline effluent are generated in agricultural drainage programs. Saline effluent from industry is also increasing, and there is a growing demand for domestic water which, in a number of arid regions, is being met by desalination plants - which in turn generate saline effluent.

The generation of saline effluent, whether from direct desalination, land salinisation or industry is normally viewed as a severe environmental problem - which in most cases it is. However, there may be opportunities to utilise this saline effluent, 
particularly in the desalination industry. This paper will look at how saline effluent could be used, and better integrated with the whole 'life cycle' of desalination (ie feedwater, desalination, and disposal of saline 'waste' streams). With significant desalination plant capacity scheduled to come on-line during the next five years, this will be of increasing importance in the years ahead.

Brine disposal is normally seen as a major issue in the engineering design of any desalination facility - yet consideration of brine disposal, or its utilisation, often appears to be an afterthought in many desalination texts. Utilisation of waste streams for saleable chemicals, or as 'raw materials' for other applications such as solar pond (or salinity gradient ponds) electricity generation, has generally been regarded as uneconomic. However, the sheer volume of 'waste streams' generated by the rapidly growing desalination industry, as well as improving technology which is lowering the costs of processing brine, has opened up a number of opportunities to improve the efficiency of the total process of desalination (which by necessity, includes 'waste disposal')

This paper will focus on the use of the saline 'waste stream' from desalination plants, particularly on solar ponds to generate electricity, and recovery of resources from the bitterns, but within the context of the 'total cycle of production'.

\section{Current Situation}

Cogeneration of electricity and desalinised water is an accepted principle in many countries (eg see Buros, 1990). However, there is an opportunity to extend this by the further processing of the brine, or bitterns, byproduct of desalination.

Most coastal desalination plants dispose of 'waste streams' directly to the sea. However, options for the disposal of 'waste streams' from inland desalination plants have generally been limited to direct soil infiltration; deep bore injection; off-site disposal (to the sea, rivers or dry watercourses) and evaporation/open pond. Direct soil infiltration is normally only a practical option for the smaller desalination plants (eg see Herbert and Moffat, 1970), and is not discussed further here. Deep well injection of brine is extensively used in the petroleum industry, but not favoured for desalination plants due to the much larger volumes involved (Howe, 1974), and the risks of freshwater aquifer contamination.

To date, the focus on saline effluent from desalination plants has been on 'waste disposal'. While there may be some problems with the use of evaporation basins (for example, see Ahmed et al, 1999), they do provide an opportunity for reuse. The value-adding opportunities which are associated with the use of evaporation basins need to be assessed for economic and environmental viability.

\section{Pretreatment opportunities}

Salutsky and Dunseth (1963) outlined research done over thirty years ago to assess the feasibility of preparing fertiliser from scale-forming chemicals after treating seawater with anhydrous ammonia and phosphoric acid. They found the 
predominately magnesium-ammonium-phosphate fertilisers produced have low solubility and are therefore slow leaching in sandy soils.

How is this relevant to bitterns? Since reducing the scale problem will allow greater efficiency of distillation, it may also have an effect on the volume of water, and bitterns, produced. Additionally, if the original feedwater has had calcium, magnesium and other heavy metals removed by phosphate precipitation, the brine from distillation plants can be used for the production of caustic soda and chlorine in a diaphragm cell (Salutsky and Dunseth, 1963).

\section{Desalination}

The actual process of desalinisation has been discussed in detail in a number of texts, and will not be discussed here. However, cogeneration, or dual purpose, plants (using a single energy source to perform several functions) has obvious application to better integration and improved efficiency of water and salt production. Distillation plants built as combined electricity generation/water production units can significantly reduce the consumption of fuel, when compared to independent electricity and desalination plants (Buros, 1990). While this may create a problem with water production when the electricity generator is down for repairs, linking solar ponds as electricity generators into the circuit can provide backup (see figure 4). Waste heat can in turn be used to assist solar pond performance. Having the cogeneration infrastructure in place may also make pretreatment of saline feedwater more feasible.

\section{Post treatment}

The use of evaporation basins provides flexibility and increased opportunities for saline effluent utilisation. Some of these opportunities are as follows:

(a) Use of evaporation ponds for production of fish, brine shrimp and betacarotene

Aquaculture is a growing industry. Moderately saline effluent can be used to culture fish though rigorous monitoring is required (see Cookes Plains case study insert). Species reported to grow well in high salinity water in Australia are brine shrimp (Artemia salina), Barramundi (Lates calcarifer), Black Bream (Acanthopagrux butcheri), Red Snapper (Pagrus auratus), Milk Fish (Chanos chanos), Mullet (Mugil cephulux) and Tilapia (Oreochromis mossambicus). Having brine shrimp production downstream from finfish culture has advantages in that the brine shrimp utilise nutrients generated from fish culture, while providing food for fish fry.

Evaporation basins can also provide a foundation for algae production. Dunaliella salina grows and produces commercial grades of beta-carotene at salinities greater than $200 \mathrm{~g} / \mathrm{L}$. Other species of salt tolerant 'algae' (more correctly, a blue green bacteria) may also have commercial application. 
The Bedford Groundwater Interception project, at Cookes Plains, in Australia, uses evaporation basins to hold saline effluent. Products from the evaporation ponds include:

- Fin fish culture (bream and barramundi). Snapper were successfully grown, until the population crashed in January, 1998 (which was attributed to high levels of iron and manganese in the groundwater, with iron precipitates clogging fish gills Hutchinson, undated). This experience led to recommendations for water treatment, based on vigorous aeration of all inflowing groundwater, with separate storage (1-2 days) to allow precipitation of iron oxides, then mechanical filtration to remove other remnant precipitates, before transfer into header tanks for use in aquaculture.

- Brine shrimp production. Brine shrimp (Artemia salina) were introduced to clean up organic matter in the evaporation ponds, but were found to also have commercial application (sold to pet shop suppliers for tropical fish, with the balance being fed to fin fish on site as a food supplement).

- Beta-carotene, extracted from Dunaliella, which grows in the concentrated brine. The Dunaliella were introduced to the brine (specific gravity of 1.16) in $7.6 \times 40 \mathrm{~m}$ plastic lined channels, holding approximately $90 \mathrm{cu} \mathrm{m}$ brine at $0.3 \mathrm{~m}$ depth. Growth of the Dunaleilla was reported to be exceptional, with counts of more than 400,000 cells/mL Dunaleilla after eight weeks (Fisher, 1998).

- Salt, used for preserving hides and skins, as well as in stock feeds

- Bitterns, left after salt harvesting, which is used as a road stabiliser, and soil conditioner.

Although the Cookes Plains project is a small scale pilot, it shows what can be achieved when the 'waste' paradigm is shifted to 'resource recovery'.

\section{(b) Solar ponds}

The economic viability of salinity-gradient (solar) ponds is determined by the demand for low-grade heat, and the price and availability of alternate energy. Given that water, salt, solar radiation and flat land is readily available and that there is a valuable use for the thermal energy, a solar pond becomes attractive as a source of renewable energy (Burston and Akbarzadeh, 1995). Akbarzadeh et al (cited in Burston and Akbarzadeh, 1995) noted that a $10,000 \mathrm{~m}^{2}$ solar pond in northern Victoria (Australia) could produce the equivalent of more than $\$ A 130,000$ per year of low-grade heat where LPG or oil would be used, or generate about $200,000 \mathrm{kWh}$ of electricity per year. Capital cost was estimated at $\$ A 250,000$ to $\$ A 300,000$. This proposal is now being field tested at Pyramid Hill, Australia.

To be effective electricity generators, solar ponds require:

- all-year solar exposure

- large volumes of brine, as well as an adequate source of 'fresher' water

- cheap, flat land, of low permeability, and high thermal and structural stability

- away from shallow aquifers

- relatively low winds (to minimise mixing and deposition of debris), and

- a consistent electricity demand. 
Thermal efficiency is affected by:

- brine clarity (which relates to energy collection efficiency)

- thickness of layers within the solar pond

- maintenance of the vertical salt gradient

- pond area (min size 1 hectare-max 10 hectares)

- depth to groundwater (shallow groundwater can lead to significant heat loss)

Ideally, power generated from the solar ponds would be fed into the desalination process, or could be used for further processing of bitterns. Again, this is not a new concept. This concept was considered almost 30 years ago (Gerofi and Fenton, 1981, cited in Caldwell, 1989), when interest developed in diverting saline drainage into evaporation basins, and using energy generated from solar ponds to desalinate a portion of the effluent. Current research in Australia is aiming to develop a $3000 \mathrm{~m}^{2}$ pilot solar pond to provide heat for commercial salt production and aquaculture at Pyramid Hill in northern Victoria (Australia) (Burston, pers comm). It is being supported by the Australian Government (\$A550,000 grant) as wider application of solar pond technology has potential to reduce greenhouse gas emissions.

A salt-gradient non-convective solar pond can be considered to have three layers:

- the top, or Upper Convective Zone (UCZ). This is relatively fresh water, ideally about $30 \mathrm{~cm}$ thick. Increasing the thickness of this layer decreases the pond's ability to store heat. It is difficult to keep this less than $0.4 \mathrm{~m}$ in thickness if pond size is greater than 10 hectares.

- The gradient, or Non-Convective Zone (NCZ). The insulating zone can be 0.5 to $1.5 \mathrm{~m}$ thick, depending on the application.

- The heat storage zone, or Lower Convective Zone (LCZ). Ideally, this is a near saturated saline solution. This is best achieved by direct injection of concentrated brine into the LCZ.

Figure 1. A salt-gradient non-convective solar pond.

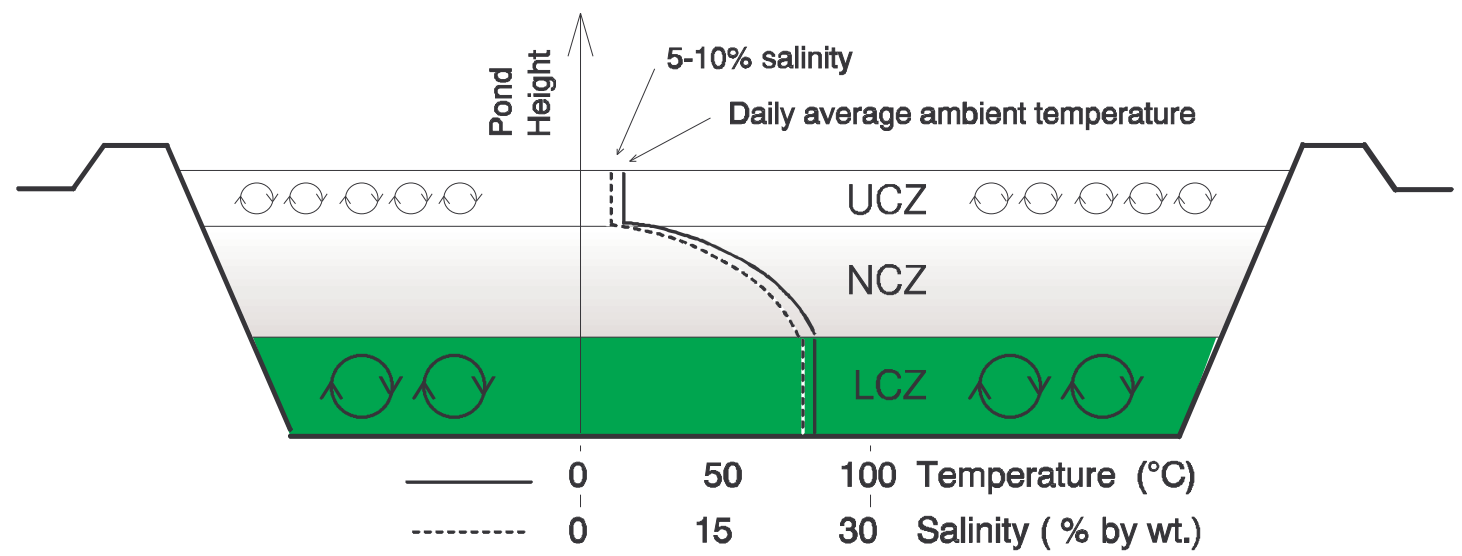

From Burston and Akbarzadeh (1995)

The US Bureau of Reclamation has funded a study (USBR, 1999) by the University of Texas at El Paso to test and evaluate the performance of a Licon Multi-effect, 
multi-stage thermal flash distillation unit powered by energy provided by a salinitygradient solar pond. However, results are not yet available

\section{(c) Resource recovery from bitterns}

The potential for recovery of a number of chemicals from both seawater and bitterns often appears paradoxical in nature. On the one hand, "the quantity of common chemical which could be recovered from desalting plan brines would greatly exceed the demand for such chemicals" (Howe, 1974). Magnesium-chloride-rich solution has several important uses as a raw material for magnesium oxide and other magnesiumcontaining chemicals, and in the oil industry (Fernandez-Lozano, 1993). On the other hand, there are few practical examples of further processing of brines from desalinisation plants. The paradigm of 'waste product' needs to be changed to that of 'resource' if utilisation of brine is to occur.

Fernandez-Lozano (1993) conducted a laboratory study to demonstrate the feasibility of recovering leonite $\left(\mathrm{K}_{2} \mathrm{SO}_{4} \cdot \mathrm{Mg} \mathrm{SO} \mathrm{SO}_{4} \cdot 4 \mathrm{H}_{2} \mathrm{O}\right)$ and magnesium-chloride rich solution from seawater saltfield bitterns. A bitterns-based product has been used as a road stabiliser (for earth-based roads in Australia) and as a dust suppressant. Research has also been conducted on the use of bitterns as a soil ameliorant (Whatmuff, 1991).

Abdel Aal et al (1990a,b) simulated the recovery of salts (mainly $\mathrm{MgCl}_{2}$ ) from desalination plant brines, using data from the Al-Khobar Desalination Plant in Saudi Arabia. Putting brine from the Al-Khobar Desalination Plant through a further 32 repeated cycles of 4 stages each gave additional potable water, $\mathrm{NaCl}$, and a highly concentrated $\mathrm{MgCl}_{2}$ bittern. (However, they also highlighted the need for further research to deal with the viscosity and corrosive aspects of the bitterns).

SAL-PROC technology takes a similar approach (Arakel, 1993), but on a larger scale. This approach is based on sequential extraction of a variety of salt minerals, slurries and liquid compounds by multiple evaporation and cooling of concentrated saline wastewaters, desulphation, reaction, crystallisation, washing and dewatering. The process is particularly suitable for brine with high levels of dissolved sulphate, potassium and magnesium salts. A simplified flow chart showing a processing option to produce a range of products while achieving zero discharge is attached (figure 2)

Linkage of SAL-PROC with a desalination plant powered by a cheap energy source (eg, waste heat energy from conventional power plants or solar energy generators) will improve SAL-PROC economics. Where a cheap energy source is available, additional processing can occur, eg for more valuable 'secondary products' such as nitrates of potassium and sodium and ammonium products. In such cases, it is expected that the benefit-cost curves (figure 3) will become more steeper (ie have a greater return) than at present for the smaller scale processing operations.

Various studies have indicated that a commercial operation using the SAL-PROC technology for the recovery of valuable products from the saline waters of Lake Tutchewop in northern Victoria (Australia) can generate significant improvements in ecological and economic values. A small saline processing demonstration plant has been established on site. All targeted saline water is used the manufacture of saleable products. This in turn generates significant benefits to the water users, the 
environment and the investors in the processing facilities. The products generated in the demonstration plant using saline lake waters are wide ranging and offer opportunities for downstream processing for value adding.

Figure 2. The SAL-PROC process (simplified)

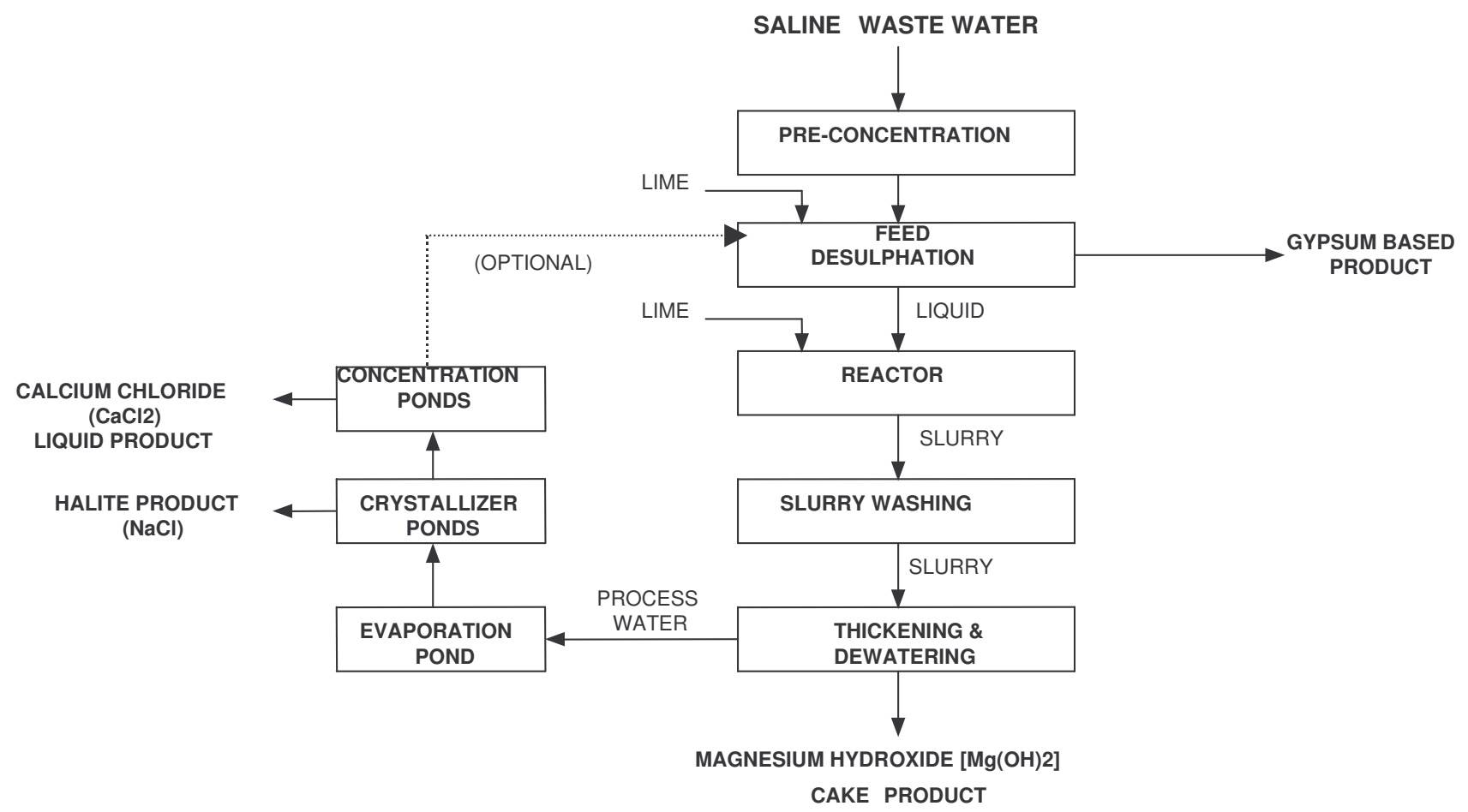

Simplified Flow Chart for a Saline Processing Route Using the SAL-PROC Technology to Achieve Zero Discharge to Environment

Figure 3: The relationship between volumes treated, effluent concentration, and economic return using the SAL-PROC process.

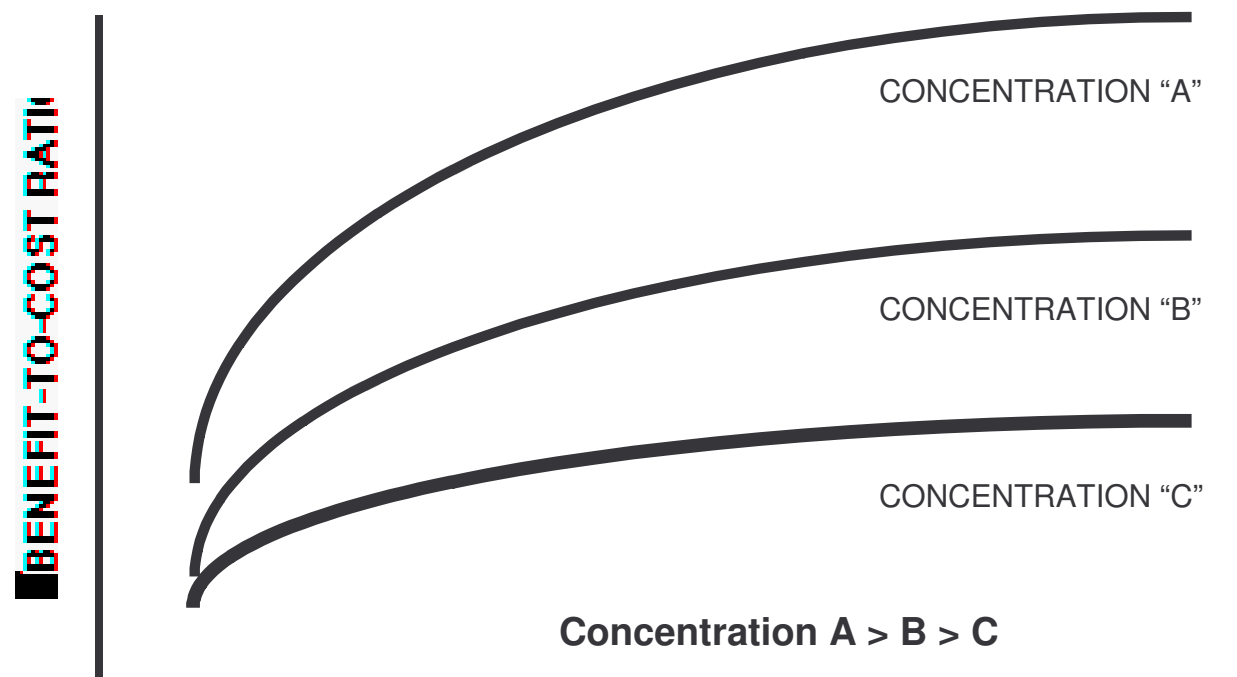

INPUT VOLUME THROUGH THE PROCESSING PLANT 


\section{The linkages}

Separate components of the saline 'waste disposal problem' have been discussed above. These include further processing of salt by-products, particularly bitterns, multiple use of evaporation basins for fish, brine shrimp and algae, electricity generation from salinity gradient solar ponds (using bitterns as the main constituent). Some small and medium scale pilot projects in Australia have been described, which give promise to the future. Integrating the cogeneration of power, water and processed salt products can have significant beneficial effects in terms of resource use in arid and semi arid regions.

The Pyramid Hill project in northern Victoria, Australia, involves a series of mediumscale ponds ( 20 hectares) designed with commercial products in mind. This area has had a long history of shallow watertable and salinity problems, and the ponds were developed as a saline effluent disposal scheme, operated by Pyramid Hill Salt Pty Ltd. The ponds cover 20 hectares out of a total farm area of 450 hectares. The project, initiated in 1994/95 and costing \$A350,000 to establish, is now fully functional.

Further value-adding includes:

- brine shrimp cultured in the ponds and harvested every 14 days. The shrimp is processed into aquarium feed. (Silver perch fish are raised in a freshwater dam nearby). Brine shrimp removes most of the calcium ions in the effluent.

- The crystallised salt is washed, dissolved and recrystallised in hothouses to produce food quality salt. The hothouses allow control of air moisture content and speed of crystallisation, and prevent dust contamination.

- highly concentrated brine (with a relatively 'fresh' surface layer of less saline water) is held in large concrete tanks exposed to sunlight, with research conducted by the Royal Melbourne Institute of Technology A Rankine engine will then be used to generate electricity. According to the manager at Pyramid Hill Salt, the electricity produced at site will supply all the needs of the scheme and be left with excess current to be passed on to the State electricity grid.

- Salt processing.

This multi-disciplinary approach, outlined in figure 4 , is likely to demonstrate significant synergies, which can translate to commercial opportunities for value adding (as against just meeting minimum environmental obligations).

For example, saline effluent from a desalination plant may be processed in a SALPROC plant to produce a magnesium based flocculating agent for dewatering of flyash slurry from a nearby coal power station. It could also be added dewatered sludge, or biosolids, as well as $\mathrm{SO}_{2}$ flue gas removal from the power station stack. The gypsum produced from $\mathrm{SO}_{2}$ removal may be used for lining the sludge disposal ponds, while calcium chloride solution produced from SAL-PROC operation used as an effective dust suppressant in the mining operations. One of future imperatives will be the need to achieve a balance between the commercial gains and environmental outcomes. This may be possible through technology integration for defining the 
minimum and optimum scale of commercial application of the smart technologies commensurate with community and government expectations.

Figure 4. Integrated Power, Water and Salt Generation

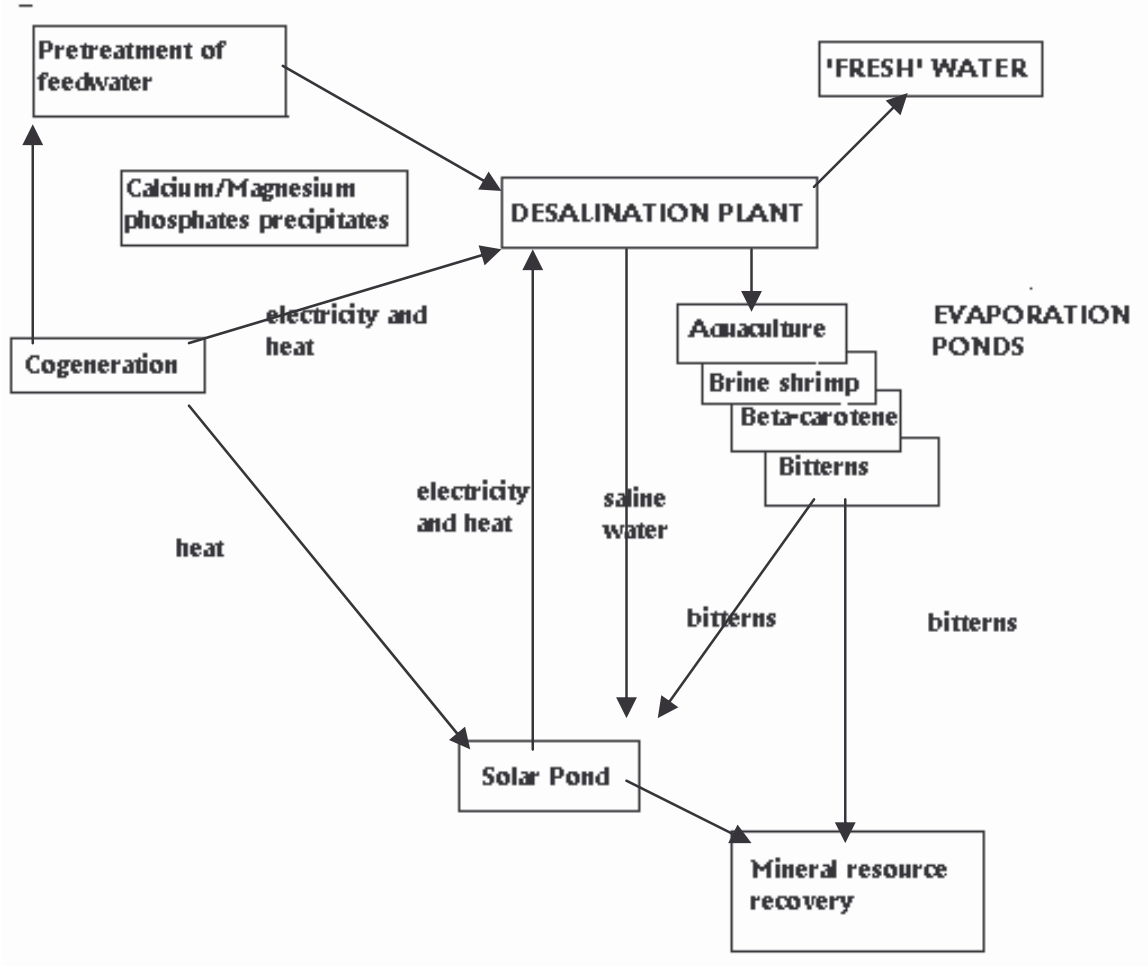

\section{Conclusion}

Cogeneration of electricity and desalinised water is a well-accepted principle in many countries. This approach needs to be extended to optimise recovery of metals from the byproducts of water production - bitterns. The waste-disposal paradigm needs to be changed in order to achieve this, and the best way of achieving this is to adapt the 'theoretical' research on resource recovery from bitterns to pilot plants, integrated to the production of potable water, and ideally linked to cogeneration plants. An overview of some applied research and small-scale trials in this field in Australia has given an indication of the potential benefits of this approach.

That these concepts work individually, there is no doubt. The challenge now, is to link the treatment of saline feedwater, with electricity generation, desalination, aquaculture, brine shrimp production, bitterns concentration and mineral resource recovery, as the one, integrated system. Achieving this at a field-scale application, would indeed be a symbol of the environmental consciousness of the desalination industry, as well as contributing returns to (what is now the 'cost' of) saline effluent 'disposal'. Given the large increase in desalination plant capacity forecast over the 
next five years, there is an urgency for this research on how best to achieve better integration, and improved efficiencies, now.

\section{References:}

Abdel-Aal, H.K., K.M Ba-Lubaid, D.K. Al-Harbi and A.A.Shaikh (1990) Recovery of Mineral Salts and Potable Water from Desalting Plant Effluents by Evaporation. Part I. Evaluation of the Physical Properties of Highly Concentrated Brines, Separation Science and Technology, 25 (3), pp 309-321, 1990

Abdel-Aal, H.K., K.M Ba-Lubaid, A.A.Shaikh and D.K. Al-Harbi (1990) Recovery of Mineral Salts and Potable Water from Desalting Plant Effluents by Evaporation. Part II. Proposed Simulation System for Salt Recovery, Separation Science and Technology, 25 (4), pp 437-461, 1990

Ahmed M., W. Shayya, J. Al-Handhaly, D. Hoey, A Mahendran, 1999. Investigation on the Use of Evaporation Ponds for Brine Disposal in Inland Desalination Plants, Draft final report ,submitted to the Middle East Desalination Research Centre (MEDRC), Oman. Pp 69.

Akbarzadeh, A. and Earl, G. (1992). Solar Ponds and Salinity Control in Victoria, in: Australian and New Zealand Solar Energy Society, Solar 1992 Conference Proceedings 5-18 July, Darwin, Australia.

Arakel, A. (1993) Salt Harvesting from Saline Wastewaters by using SAL_PROC Technology, brochure

Buros, O.K. (1990) The Desalting ABC's, prepared by the International Desalination Association, modified and reproduced by Research Department, Saline Water Conversion Corporation, Riyadh, Saudi Arabia

Burston, I. and A Akbarzadeh (1995) Integration of Solar Ponds into Salt Affected Areas, in Conference proceedings, International Symposium on Energy, Environment and Economics, Univ Melbourne, November 1995

Caldwell, B. W. (1989) Proposed Solar Pond Facility at Wakool Solar Evaporation Basins, M Eng Sc project, School of Civil Engineering, Univ NSW Project Report 8.909G

Fernandez-Lozano, J.A., (1993) Production of Potassium Sulphate-magnesium sulphate double salt and Magnesium- chloride rich solutions from seawater bitterns. Chemical Engineering Jnl, Vol 52, issue 2

Fisher, C.E. (1998). Bedford Groundwater Interception Project-Cooke Plains, A report for the Rural Industries Research and Development Corporation, internal report. 
Gerofi, J.P. and G.G. Fenton, (1981) Solar Ponds Current Status and Potential in NSW, ENERSOL Consulting Engineers Report, commissioned by the Energy Authority of NSW, 1981, cited in Caldwell,1989.

Herbert, L.S. and D.H. Moffat, (1970) Desalination - a Survey of Australian Plants, AWRC Research Project 68/6, Department of National Development, Canberra, Australia

Howe, E.D (1974) Fundamentals of Water Desalination, Marcel Dekker, New York.

Salutsky, M.L. and M.G. Dunseth (1963) Recovery of Minerals from Seawater by Phosphate Precipitation, in Saline Water Conversion-II Advances in Chemistry Series 38, American Chemical Society, Washington DC, 1963

USBR 1999 refers to http://www.usbr.gov/water/reports.html., last updated, 16/7/1999 The study cited was Turner,C.D., Walton J.C., Moncada J.D., and Tavares, M., Brackish Groundwater Treatment and Concentrate Disposal for the Homestead Colonia El Paso, Texas, Univ of Texas at el Paso, El Paso TX, April 1999.

Whatmuff, M. (1991) The effect of applied 'high magnesium' bitterns upon the physical and chemical properties of soils from Wakool-Tullakool Irrigation District, New South Wales, Australia, Land and Water Resources Research and Development Corporation report 32/91, LWRRDC, 1991, 180pp 